\title{
European mistletoe continues to spread in Sonoma County
}

\author{
Frank G. Hawksworth $\square$ Robert F. Scharpf $\square$ Melissa Marosy
}

\section{European mistletoe Niscum al- bum) was established in Sonoma County about 90 years ago and has spread a maximum of 7.5 miles and an average of 5 miles from its point of introduction in Sebastopol. The mistletoe now occurs in the nearby communities of Graton, Santa Rosa, Fulton, Cotati, Forestville and Occidental. It has been found on 23 different deciduous trees, but is most common on silver maple, apple, black locust, red al- der and Fremont cottonwood.}

The European mistletoe (Viscum album) was introduced into Sebastopol, Sonoma County, by the pioneer horticulturist Luther Burbank in about 1900. However, it was not until 1966 that Dr. John Thomas Howell of the California Academy of Sciences first reported the introduction in the scientific literature. The only other locality for European mistletoe in North America is in Victoria, British Columbia, but it has not spread there following its introduction more than 20 years ago.

Viscum album superficially resembles the native mistletoe (Phoradendron macrophyllum), which is common in the area and sometimes occurs on the same trees with European mistletoe. The European plant is more openly branched and has narrower leaves compared to the native species, which has denser branching and more oval-shaped leaves (fig. 1). Seeds of both the native and European mistletoes are dispersed by birds, mainly robins and waxwings.

\section{Spread}

The first detailed survey of European mistletoe in Sonoma County was made in 1971; subsequent surveys were made in 1986 and 1991 (fig. 2). Through notes left by Luther Burbank at the UC Davis, we were able to pinpoint the location of the introduction at Burbank's experimental area in Sebastopol. For each survey, we determined the distance of spread in $16 \mathrm{di}-$ rections from the point of introduction.

In the 1971 survey, the mistletoe was found only in Sebastopol and Graton. In

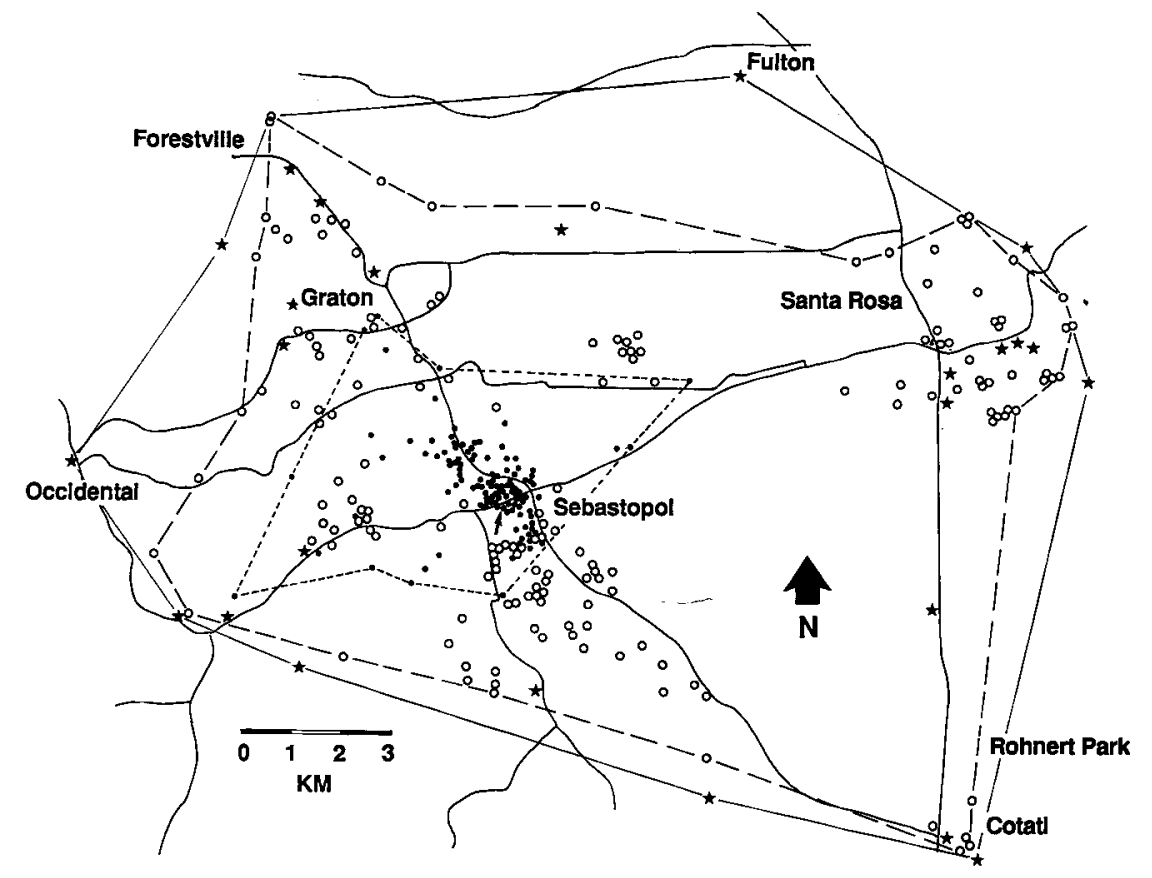

Fig. 1. Distribution of European mistletoe in 1971 (solid dots), 1986 (open circles), and 1991 (stars). Each symbol represents an infected tree or groups of infected trees. The point of introduction in Sebastopol is indicated by the arrow. The 1971 survey shows all sites then known. The 1986 and 1991 surveys concentrated on outlying areas not previously known to be affected, but all infected trees found in those years are shown.

1986, it was found in Forestville, Santa Rosa and Cotati, and in 1991, in Fulton and Occidental for the first time. In 1971, the average distance of spread from the point of introduction was 1.5 miles, or an average spread of about 0.02 miles per year for the first 70 years (table 1 ). The rate of spread increased dramatically during the next 15 years and, in 1986, the average distance of spread was 3.9 miles, and the average annual spread of 0.16 miles per year was about eight times the rate prior to 1971 . The average distance in the 1991 survey was 5 miles and the rate of spread was 0.22 miles per year since 1986 .

We believe that the rates of spread of the mistletoe will soon decline because the parasite has reached it potential limit in many directions in this area, due to the lack of suitable hosts. For example, we anticipate little future spread to the west because that area is mainly coniferous forest. Similarly, there will be limited spread to the south because that area is mostly open grassland with scattered Eucalyptus groves, but very few potential hosts.

\begin{tabular}{|c|c|c|c|c|}
\hline Year & $\begin{array}{c}\text { Distance: } \\
\text { range }^{*}\end{array}$ & $\begin{array}{c}\text { Distance: } \\
\text { average }\end{array}$ & $\begin{array}{c}\text { Annual rate } \\
\text { of spread }\end{array}$ & $\begin{array}{l}\text { Approximate } \\
\text { gross area }\end{array}$ \\
\hline & miles & miles & miles/year & square miles \\
\hline 1971 & $0.8-2.8$ & 1.5 & 0.02 & 10 \\
\hline 1986 & $2.2-7.5$ & 3.9 & 0.16 & 63 \\
\hline 1991 & $2.7-7.5$ & 5.0 & 0.22 & 71 \\
\hline
\end{tabular}




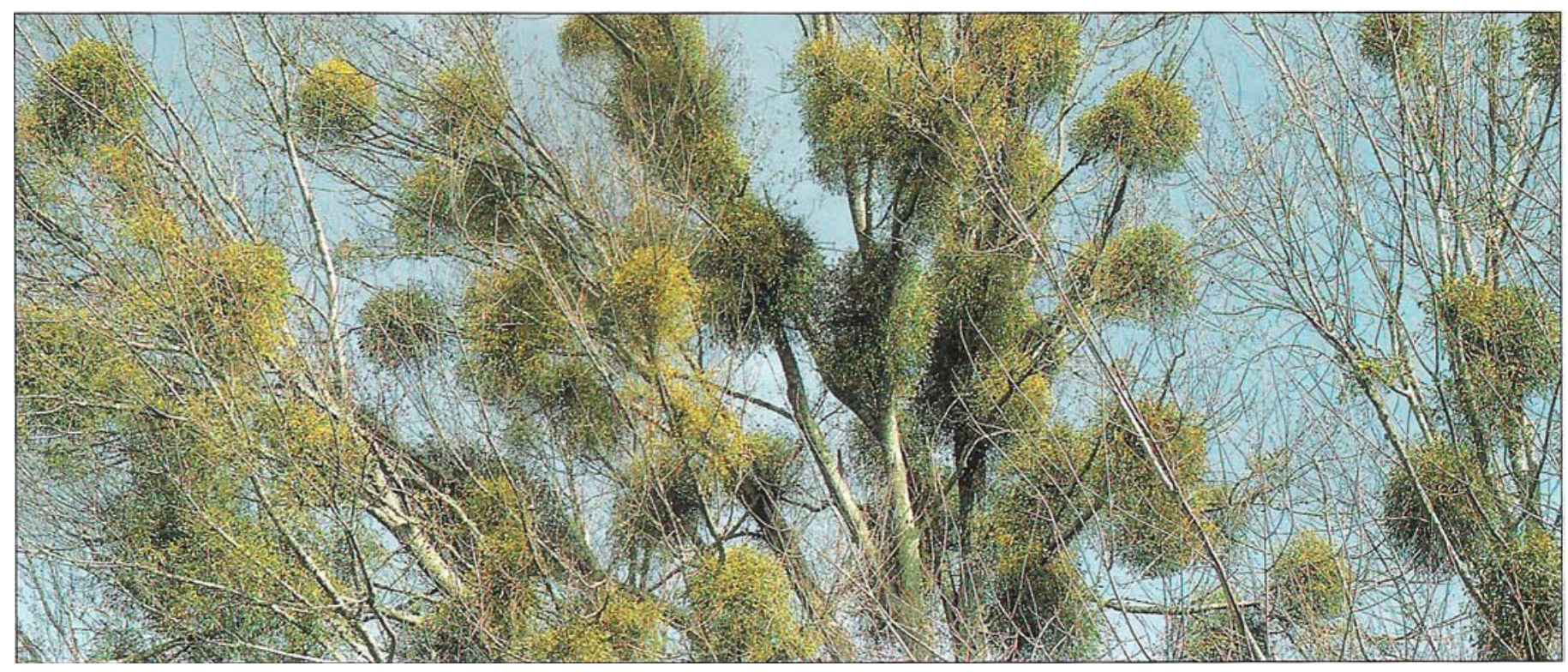

In Graton, a silver maple heavily infected by European mistletoe.

\begin{tabular}{|ll|}
\hline \multicolumn{2}{|c|}{ TABLE 2. Hosts of European mistletoe in } \\
Sonoma County
\end{tabular}

Spread to the eastern suburbs of Santa Rosa will also be limited because these are mainly oak woodlands and the European mistletoe has not been found on California oaks.

No comprehensive inventories of the number of trees affected have been made since the 1971 survey, which showed 310 infected trees. A partial survey in 1986 showed an additional 244 infected trees. The 1991 survey was concentrated in the peripheral areas and noted about 100 additional infected trees. Many infected trees have been pruned or removed, and we estimate that there are fewer than 1,000 infected trees in this area in Sonoma County.

\section{Hosts}

In Europe, this mistletoe occurs on nearly 100 different kinds of trees, but it is most common on apple, cottonwood, birch, basswood, black locust and elms; it is very rare on oaks. In Sonoma County, we have found European mistletoe on 23 hosts, including 5 native trees (table 2). Further observations would probably reveal additional hosts. The most commonly infected trees are the introduced silver maple, apple and black locust, and the native red alder and Fremont cottonwood.

It is difficult to determine which hosts are most susceptible because mistletoe-infected trees are frequently pruned and, if they are severely infected, they may be removed. For example, apple is a very susceptible host, but most mistletoe plants are removed during routine pruning operations in commercial orchards, so the mistletoe is common on apple only in abandoned orchards. Silver maple is widely planted as an ornamental tree in this area. It is the most commonly infected host; some heavily infected trees may bear hundreds of mistletoe plants. European mistletoe is common and damaging on na- tive red alder in one area west of Sebastopol near the junction of Bodega Highway and Sexton Road. Infection here is so heavy that several trees have died. Curiously, infection of red alder elsewhere is light. Black locust is commonly infected in some areas, notably in central Sebastopol. European mistletoe has not been found on eucalyptus, oaks or any conifers in Sonoma County.

\section{Conclusions}

The European mistletoe is a serious tree disease agent in many parts of Europe. Because it has such a wide host range and large latitudinal range in Europe (from Spain to southern Sweden), the potential exists for it to become widespread in California and elsewhere along the Pacific Coast. However, in spite of its dispersal by birds, the spread over the 90 years since its introduction in Sonoma County has been localized and generally confined to within 8 miles of the point of introduction.

We recommend that the situation in Sonoma County should be monitored at 5or 10-year intervals to determine the rates of spread of European mistletoe and to see if it invades other areas in Sonoma or adjacent counties. At some future date, quarantines or eradication programs may be warranted to limit spread of this potentially damaging tree parasite.

F. G. Hawksworth is Plant Pathologist with the USDA Forest Service, Rocky Mountain Forest and Range Experiment Station, Fort Collins, Colorado; R. F. Scharpf is Plant Pathologist with the USDA Forest Service, $P a-$ cific Southwest Forest and Range Experiment Station and Faculty Affiliate with the Department of Plant Pathology, UC Berkeley; and $M$. Marosy is Plant Pathologist with the USDA Forest Service, Pacific Southwest Region, Forest Pest Management, San Francisco. 